\author{
О. Демидюк, \\ аспірант \\ Академії адвокатури України
}

\title{
МОДЕЛЬ ОРГАНІЗАЦІЇ ВИЩОЇ РАДИ ПРАВОСУДДЯ: ТЕОРЕТИКО-ПРИКЛАДНИЙ АНАЛІЗ
}

У 2016 р. на рівні Основного Закону держави відбулися суттєві зміни, які торкнулися трьох ключових для реалізації функції правосуддя інститутів: суду, адвокатури та прокуратури. Їх кардинальні перетворення закономірно зумовили трансформацію окремих органів, що їх репрезентують у суспільстві. Зокрема, у межах реалізації судової реформи відбулася реорганізація Вищої ради юстиції, у результаті якої було утворено Вищу раду правосуддя (ВРП) - орган державної влади 3 конституційним статусом, відповідальний за забезпечення незалежності судової влади в державі.

Значна концентрація у ВРП широкого кола різноманітних повноважень, зокрема й щодо питань суддівської кар'єри, істотно змінила статус і роль цього органу у системі судової влади порівняно з попередніми роками його діяльності. Це, своєю чергою, зумовило нову хвилю уваги до нього з боку представників наукового співтовариства, які зосередилися на актуальних питаннях функціонування ВРП.

Так, серед сучасних актуальних наукових праць, в яких розглядається проблематика статусу та діяльності ВРП, варто, перш за все, виділити монографічне дослідження Ю.О. Косткіної, яка одна $з$ перших звернулася до аналізу ii оновленого статусу [1]. Окремі ж аспекти трансформації та функціонування ВРП стали також предметом наукового аналізу таких вітчизняних дослідників, як Л.М. Москвич [2], С.В. Прилуцький [3], С.I. Пушкар [4], О.3. Хотинська-Нор [5] та ін.
Проте чимало проблем, що стосуються правового статусу ВРП, залишаються мало дослідженими з урахуванням відносно незначного темпорального проміжку їі діяльності та нещодавніх законодавчих спроб удосконалити окремі аспекти іi функціонування. Останні, зокрема, були спрямовані на зміну організаційної структури цього конституційного органу, що вимагає звернути на неї нашу увагу.

Мета статті полягає у науковому аналізі та оцінці існуючої організаційної структури (моделі) ВРП.

Отже, ст. 131 Основного Закону держави декларує, що в Україні діє ВРП. А ї статус безпосередньо конкретизовано у Законі України «Про Вищу раду правосуддя» (Закон про ВРП). Саме норма останнього (ст. 1) визначає ВРП як колегіальний, незалежний конституційний орган державної влади та суддівського врядування, який діє в Україні на постійній основі для забезпечення незалежності судової влади, ii функціонування на засадах відповідальності, підзвітності перед суспільством, формування доброчесного та високопрофесійного корпусу суддів, додержання норм Конституції і законів України, а також професійної етики в діяльності суддів і прокурорів.

Законодавчо передбачена мета функціонування ВРП зумовлює реалізацію нею численних повноважень. Їх розмежування, своєю чергою, безпосередньо впливає на організацію роботи ВРП, визначаючи іï структуру, що природно пов'язано з потребою в ефективному управлінні організацією. Саме 
для цілей останнього необхідно, щоб структура організації відповідала їі меті та завданням і була пристосована до них. Як зазначається у підручниках із державного управління, організаційна структура - це каркас, що $€$ основою для формування окремих адміністративних функцій. Організаційна структура органу є його внутрішньою структурою і визначає склад, величину, розміщення, профіль діяльності, відповідальність, підпорядкованість, взаємодію та розподіл функцій за підрозділами. Структура (від лат. structura - «будова», «розташування», «порядок») відображає склад елементів, внутрішню форму організації системи, типовість зв'язків. Структура не тільки фіксує характеристику системи, а й описує ї̈ устрій, що дає змогу простежити розвиток цієї системи. Організаційна структура органу державної влади - це сукупність структурних елементів (підрозділів, посадових осіб та ін.) та взаємозв'язок між цими структурними елементами. Структура - невід'ємний атрибут організаційних систем, вона сприяє збереженню стійкого стану системи, тому надає їй цілісності та є показником ї зорганізованості. Організаційна структура органу державної влади залежить від місця органу в організаційній структурі державного управління, обсягу та змісту його компетенції і, відповідно, ролі в управлінні суспільними процесами $[6$, с. 8-9].

Як ми зазначали вище, організаційна структура ВРП зумовлена, перш за все, іiі законодавчо визначеним статусом і повинна повноцінно та ефективно забезпечувати виконання покладених на неї функцій, які опосередковуються низкою повноважень, закріплених у ст. 131 Конституції України та розвинутих у ст. 3 Закону про ВРП. Оскільки перелік останніх $€$ невичерпним i за своєю правовою природою та змістом діяльності у багатьох випадках вони $є$ спорідненими, доцільно говорити саме про функції, розуміння яких здебільшого зводиться до основних напрямів діяльності суб’єкта, що створюють уявлення про його місце в системі органів державної влади. Так, B.I. Татьков зазначав, що «функції Вищої ради юстиції можна розглядати як основні напрями діяльності, що визначають ї місце й загальне призначення в механізмі держави, порядок взаємодії 3 іншими державними органами, установами та організаціями». Він же виділяв такі функції, як: формування суддівського корпусу (кадрова); забезпечення незалежності суддів і правової захищеності прокурорів; дисциплінарна; представницька; організаційно-управлінська [7].

Справедливо буде зауважити про існування різних наукових класифікацій функцій ВРП. Але, щоб не вдаватися до їх аналізу та не відходити від предмету нашого дослідження, ми пристанемо на позицію Ю.О. Косткіної, яка крізь призму класифікації існуючих сьогодні повноважень ВРП виокремила такі їі функціі: кадрову, дисциплінарну, контрольну, організаційно-управлінську, функцію забезпечення незалежності судових органів та авторитету правосуддя, інформаційну, нормативну та представницьку [1, с. 72-73].

У контексті організаційної структури ВРП наведені функції законодавчо втілені у вигляді конкретних, вузько специфічних завдань іï окремих структурних елементів. Але перш ніж це продемонструвати, необхідно окреслити існуючу структуру ВРП, що передбачена профільним законом.

Так, як випливає 3 аналізу положень гл. 5 Закону про ВРП, цей орган судової влади за загальним правилом діє у пленарному складі, тобто засідає за участі всіх членів організації, а його структура передбачає функціонування таких відносно автономних структурних елементів, як: дисциплінарні палати, секретаріат ВРП, Служба інспекторів ВРП, Комісія 3 питань вищого корпусу державної служби в системі правосуддя.

Формулювання, закріплене у ст. 26 Закону про ВРП, відповідно до якого «Вища рада правосуддя діє у пленар-

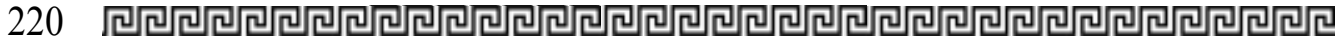


ному складі, якщо інше не встановлено цим Законом», дає можливість припустити, що пленарні засіданні ВРП $є$ основною формою іï діяльності. У пленарному складі ВРП приймає остаточні рішення з питань внесення Президентові України подання про призначення на посаду судді; щодо порушення суддями i прокурорами вимог несумісності; про звільнення судді з посади; про тимчасове відсторонення судді від здійснення правосуддя в порядку дисциплінарної відповідальності; про затвердження консультативних висновків щодо законопроєктів із питань утворення, реорганізації чи ліквідації судів, судоустрою і статусу суддів; про порушення дисциплінарного провадження стосовно осіб, суб'єктом призначення яких є ВРП.

Наведене свідчить, що саме пленарний склад ВРП повною мірою реалізує комплекс іï функцій. Водночас на структурні одиниці ВРП покладається реалізація окремих із них, що постають як конкретні завдання.

Так, дисциплінарні палати функціонують задля розгляду справ щодо дисциплінарної відповідальності суддів (ч. 2 ст. 26 Закону про ВРП), секретаріат - для організаційного, інформаційно-довідкового та іншого забезпечення діяльності ВРП (ч. 1 ст. 27 Закону про ВРП), Служба інспекторів - для забезпечення здійснення членами ВРП своїх повноважень (п. 1.2. Положення про інспектора Вищої ради правосуддя), Комісія з питань вищого корпусу державної служби в системі правосуддя (діє при ВРП, а не у ї складі) - для вирішення питань державної служби в системі правосуддя (ч. 5 ст. 29 Закону про ВРП).

Така законодавчо передбачена структура ВРП пов'язана не лише з питанням належної та ефективної організаціï роботи цього органу, а й зумовлена чинниками набагато більшого масштабу. Зокрема, у контексті автономного існування дисциплінарних палат ВРП варто нагадати рішення ЄСПЛ у справі «Олександр Волков проти
України», в якому було констатовано серйозні вади в організації системи судової дисципліни в Україні. В основу такого висновку було покладено окремі положення Спільного висновку Венеціанської комісії та Директорату з питань співробітництва Генерального директорату з прав людини та правових питань Ради Європи (м. Венеція, 15-16 жовтня 2010 р., CDL-AD(2010)029). Зокрема, з приводу того, що «член Вищої ради юстиції, який вносить пропозицію, повинен бути позбавлений можливості брати участь у прийнятті рішення щодо звільнення з посади відповідного судді: це може вплинути на гарантію безсторонності...» [8].

Окрім того, у Висновку № 10 (2007) Консультативної ради європейських суддів до уваги Комітету міністрів Ради Європи про судову раду на службі суспільству (Висновок КРЕС № 10) зауважено, що «слід усвідомлювати та враховувати той факт, що може існувати конфлікт між різними функціями судової ради... Одним зі шляхів уникнення такого конфлікту є розмежування різних завдань між різними органами судової ради» [9, с. 452-473].

Слід звернути увагу, що організаційна структура ВРП є динамічною. Окрім згаданих законодавчо закріплених структурних елементів ВРП, ВРП своїм рішенням може утворювати інші органи для виконання повноважень, визначених Конституцією України, цим Законом та Законом Украіни «Про судоустрій і статус суддів» (ч. 6 ст. 26 Закону про ВРП). Так, за даними офіційного вебсайту ВРП, при ВРП створено та функціонують такі органи: Міжнародна консультативна рада, Консультативна рада голів судів при Вищій раді правосуддя, Комунікаційний комітет системи правосуддя, Робоча група для опрацювання питань щодо кількості суддів у судах, Робоча група з питань опрацювання проєкту Положення про Єдину судову інформаційно-телекомунікаційну систему, Робоча група з питань напрацювання змін до законодавства України сто- 
совно забезпечення незалежності суддів та авторитету правосуддя, Проектний офіс 3 імплементації результатів Проєкту «Підвищення ефективності процесів Вищої ради правосуддя» [10]. Усі вони утворені відповідними рішеннями ВРП або розпорядженням Голови ВРП для вирішення завдань, які, власне, відображено у назвах цих органів. Очевидно, що на відміну від тих структурних елементів, які прямо передбачені Законом про ВРП, а отже, $€$ відносно сталими, органи, утворені ВРП, можуть зазнавати трансформацій, зокрема й ліквідації, у зв'язку з досягненням мети, для якої вони створювалися. Це вказує на таку рису структурної організації ВРП, як мобільність.

Слід зазначити, що ч. 10 ст. $131 \mathrm{KoH}^{-}$ ституції України також передбачає можливість утворення в системі правосуддя органів і установ «для забезпечення добору суддів, прокурорів, їх професійної підготовки, оцінювання, розгляду справ щодо їх дисциплінарної відповідальності, фінансового та організаційного забезпечення судів». Указівки стосовно суб'єкта такого створення конституційна норма не передбачає, що допускає ймовірну варіативність.

Насамперед йдеться про закономірний законотворчий процес, який передбачає внесення змін до чинних нормативно-правових актів, зокрема і Закону про ВРП. Як приклад доцільно згадати доповнення восени 2019 р. Закону про ВРП ст. 28-1, відповідно до якої при ВРП передбачалося утворення та функціонування Комісії 3 питань доброчесності та етики (Комісія) з метою забезпечення прозорості і підзвітності членів ВРП та членів Вищої кваліфікаційної комісії суддів України. Окрім того, на цю Комісію було покладено здійснення моніторингу інформації про суддів Верховного Суду 3 метою виявлення дисциплінарних порушень. Проте для багатьох було очевидно, що повноваження, якими наділялася Комісія, порушували задекларований в Україні єдиний статус суддів, а також суперечили правовій природі ВРП - незалежному органу, при якому, власне, створювалася Комісія. Тому очікуваним було рішення Конституційного Суду України, який, надавши оцінку відповідним положенням законодавчих актів, якими вносилися зміни до Закону про ВРП і які регулювали окремі питання їі діяльності у «перехідний» період, зробив висновок, що «Комісія наділена повноваженнями щодо контролю над діяльністю членів Вищої ради правосуддя та суддів Верховного Суду, проте ці повноваження не мають конституційної основи». Суд конституційної юрисдикції також зазначив, що «орган, установу, утворені при конституційному органі, закон не може наділяти контрольною функцією щодо цього конституційного органу» [11].

Рішенню Конституційного Суду України передував аналогічний із цього питання висновок Венеціанської комісії, яка застерігала вітчизняного законодавця від створення додаткового спеціалізованого органу (Комісіі), наголошуючи, що такий крок ще більше ускладнює існуючу систему органів судової влади. Зокрема, вона зауважила таке: «Комісія з питань доброчесності та етики є своєрідним наглядовим органом за обома органами, яка оцінює відповідність їхніх членів «принципам добросовісності та етичних норм судді, які $€$ невід'ємним складником професійної етики...» [12].

Слід зауважити, що застосований Конституційним Судом України та Венеціанською комісією підхід цілковито узгоджується 3 рекомендаціями, що містяться у Висновку КРЕС № 10. Йдеться, зокрема, про таке: «Окрім певної ролі в управлінні судовою системою, судова рада повинна також бути автономним органом судової влади, який забезпечує здійснення суддями своїх функцій, запобігаючи будь-якому контролю з боку виконавчої та законодавчої влади й неналежному впливу всередині судової системи. У цьому контексті КРЕС уважає, що буде неприпустимим, якщо судова рада обмежуватиметься іншими органами 
у своїй автономії визначати власні процедури діяльності та питання, що виносяться на їі розгляд» [9, с. 454].

Отже, підходи до зміни структури ВРП як органу, відповідального за забезпечення незалежності судової влади в державі, повинні бути виваженими та такими, що не посягають на фундаментальні цінності демократичної держави, не створюють загрози невиправданого запровадження контролю над ним. Вони повинні бути спрямованими на оптимізацію роботи ВРП та забезпечення ефективної реалізації ii функцій.

До прикладу, керівник секретаріату ВРП С.I. Пушкар зауважує про можливість створення у структурі ВРП бек-офісу - структурного підрозділу, що відповідатиме за виконання невисококваліфікованої роботи, проте такої, яка потребує значних ресурсних та часових затрат. Така ініціатива (рекомендація) виникла у результаті аналізу діяльності ВРП у рамках Проєкту «Підвищення ефективності процесів Вищої ради правосуддя», презентованого Компанією KPMG за підтримки Програми USAID «Нове правосуддя» [4].

У підсумку зазначимо, що існуюча структура ВРП організована з урахуванням (під впливом) трьох чинників: 1) міжнародних стандартів; 2) чинного законодавства України; 3) ініціативи ВРП, зумовленої потребою ефективного функціонування. Вона також характеризується такими рисами, як динамічність і мобільність. Водночас іï основу становлять сталі структурні елементи, існування яких прямо передбачено законом. Утворення інших органів у структурі ВРП можливе як результат законотворення або локального нормотворення. Головними та обов'язковими умовами повинні бути забезпечення незалежності ВРП та ефективна реалізація ї̈ функцій.

Стаття відображає результати наукового аналізу існуючої організаційної структури (моделі) Вищої ради правосуддя.
Констатується, що в результаті внесення у 2016 р. змін до Основного Закону держави щодо правосуддя відбулася реорганізація Вищої ради юстищіi у Вищу раду правосуддя (ВРП). Значна кониентрація у ВРП широкого кола різноманітних повноважень, зокрема й щодо питань суддівської кар'єри, істотно змінила cmamyс і роль иього органу у системі судової влади порівняно з попередніми роками його діяльності. Це привернуло увагу до діяльності ВРП не лише науковців, а й нового складу парламенту. Незважаючи на відносно нетривалий час роботи оновленого органу суддівського врядування, законодавець вирішив створити у iï структурі новий орган. Цей крок зазнав критики з боку міжнародних інституизй, а Конституціійний Суд України визнав відповідні законодавчі положення неконституційними.

Автор зазначає, що організаційна структура ВРП зумовлена, перш за все, ті законодавчо визначеним статусом $i$ повинна повноцінно та ефективно забезпечувати виконання покладених на неї функиій. Повною мірою ї реалізуе пленарний склад ВРП. Водночас на структурні одиниці ВРП покладається реалізація лище окремих із них, що постають як конкретні завдання.

На підставі системного аналізу норм чинного законодавства та локальних актів ВРП зроблено висновки про те, щзо існуюча структура ВРП організована з урахуванням (під впливом) трьох чинників: 1) міжнародних стандартів; 2) чинного законодавства України; 3) ініціативи ВРП, зумовленої потребою ефективного функиіонування. Вона e динамічною та мобільною. При цьому ї основу становлять сталі структурні елементи, існування яких прямо передбачене законом. Утворення інших органів у структурі ВРП можливе як результат законотворення або локального нормотворення. 


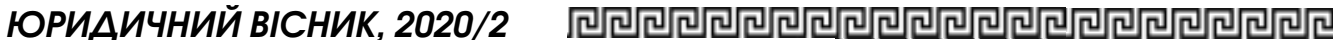

Автор наголошуе, що підходи до зміни структури ВРП як органу, відповідального за забезпечення незалежності судової влади в державі, повинні бути виваженими та такими, що не посягають на фундаментальні иінності демократичної держави, не створюють загрози невиправданого запровадження контролю над ним. Вони повинні бути спрямованими на оптимізацію роботи ВРП та забезпечення ефективної реалізації їі функцій.

Ключові слова: Вища рада правосуддя, суддівське врядування, судова рада, структура Вищої ради правосуддя, організація Вищої ради правосуддя.

Demydiuk 0 . The model of orgasnization of the High Council of Justice: theoretical and applied analysis

As a result of amendments to the Constitution in 2016, the High Council of Justice was reorganized. Many different powers were concentrated in the HCJ. This has significantly changed its status and role in the judiciary comparing to previous years. And also catch the attention of scholars and the new parliament. Although the HCJ has not been operating for so long, the legislator has decided to create a new unit in its structure. This step was criticized by the Venice Commission, and the Constitutional Court of Ukraine declared the relevant legislative provisions as unconstitutional.

The above prompted the author to pay attention to the existing organizational structure (model) of the High Council of Justice. Its scientific analysis became the purpose of this publication.

The author notes that the organizational structure of $\mathrm{HCJ}$ depends on its status, which is defined by law, and the functions that must be effectively performed. All functions are implemented by the plenary composition of the HCJ. This is the main form of its activity. At the same time, HCJ structural units implement only certain functions that appear as specific tasks. Based on a systematic analysis of current legislation and local acts of the HCJ, the following conclusions are made. The existing structure of $\mathrm{HCJ}$ is organized considering (under the influence) three factors: 1) international standards; 2) current legislation of Ukraine; 3) HCJ initiative related to its need for effective functioning. It is dynamic and mobile. At the same time, it is based on stable structural elements, which existence is directly provided by law. Creation of other units in the structure of HCJ is possible as a result of legislation or local rule-making. The author emphasizes that approaches to changing the structure of the HCJ should be balanced and not encroach on the fundamental values of a democratic state, not to produce a threat to the unjustified establish of control over it. They should be aimed at optimizing work of HCJ and ensuring the effective implementation of its functions.

Key words: High Council of Justice, Judicial Governance, Judicial Council, structure of the High Council of Justice, organization of the High Council of Justice.

\section{Література}

1. Косткіна Ю.О. Правовий статус Вищої ради правосуддя: теорія та практика : монографія. Київ : Алерта, 2019. $268 \mathrm{c}$.

2. Москвич Л.М. Чи має суддя право на судовий захист? Актуальні проблеми судово-правової реформи : матеріали круглого столу, м. Одеса, 18 жовтня 2019 p. Oдеса : Фенікс, 2019. URL : https: // drive.google.com / file/d/1GB4gFq_CO3_ Q55v79qJCWSSXAKDN8AGw/view.

3. Прилуцький С.В. Судові повноваження Вищої ради правосуддя: правове регулювання та перспективи вдосконалення. Актуальні питання кримінального права, процесу і криміналістики, удосконалення діяльності судової $i$ правоохоронноі систем : матеріали Всеукр. наук.-практ. конф., м. Сєвєродонецьк, 19 травня 2017 р. Сєвєродонецьк, 2017. С. 315-316.

4. Пушкар С.I. Новели та пропозиціі законодавчого регулювання діяльності

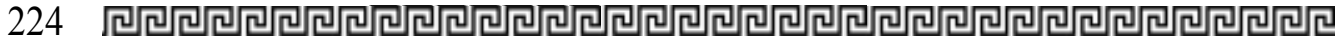


Вищої ради правосуддя. Актуальні проблеми судово-правової реформи : матеріали круглого столу, м. Одеса, 18 жовтня 2019 p. Oдеса: Фенікс, 2019. URL : https: / / drive.google.com / file/d/1GB4gFq_CO3_ Q55v79qJCWSSXAKDN8AGw/view.

5. Хотинська-Нор О.3. Теоретико-правові та праксеологічні засади судової реформи в Україні : дис. ... докт. юрид. наук. Київ, 2016. 472 с.

6. Євтушенко О.Г., Андріяш В.I. Державне управління : навчальний посібник : у 3-х ч. Миколаїв : ЧДУ ім. Петра Могили, 2014. 4. 3. 248 c.

7. Татьков B.I. Вища рада юстиції як конституційний орган зі спеціальним статусом. Вища рада юстиції в контексті судово-правової реформи. С. 123-126. URL : http://wwrevru.gov.ua/content/ file/15vrubook116-185.pdf.

8. Рішення Европейського суду з прав людини від 09.01.2013 у справі «Олександр Волков проти України» (заява № 21722/11). URL : https://zakon.rada. gov.ua/laws/show/974_947.

9. Висновок № 10 (2007) Консультативної ради європейських суддів до уваги Комітету міністрів Ради Європи про судову раду на службі суспільству. Документи Консультативної ради європейських судаів : офіційне видання / упоряд.
A.O. Кавакін ; 2-е вид., доп. Київ : Iн Юре, 2017. 816 c.

10. Офіційний вебсайт Вищої ради правосуддя. URL : http://www.vru.gov.ua/ add_text / 211.

11. Рішення Конституиійного Суду України від 11 березня 2020 року № 4-p/2020 у справі за конституиійним поданням Верховного Суду щодо відповідності Конституиї України (конституиійності) окремих положень законів України «Про судоустрій $і$ статус суддів» від 2 червня 2016 року № 1402-VIII, «Про внесення змін до Закону України «Про судоустрій $і$ статус суддів» та деяких законів України щодо діяльності органів суддівського врядування» від 16 жовтня 2019 року № 193-IX, «Про Вищу раду правосуддя» від 21 грудня 2016 року № 1798-VIII. URL : http: / / www.ccu.gov.ua / docs $/ 3050$.

12. Висновок Європейської комісії «За демократію через право» (Венеціанська комісія) щзодо змін до законодавчих актів, які регулюють статус Верховного Суду та органів суддівського врядування, від 9 грудня 2019 р. № 969 / 2019. URL : https: / / www.echr.com.ua/document / visnovokshhodo-zmin-do-zakonodavchix-aktiv-yakiregulyuyut-status-verxovnogo-sudu-taorganiv-suddivskogo-vryaduvannya/. 